\title{
O LOUCO DO CATÍ: O NASCER DA IDENTIDADE
}

\section{O Louco do Cati: the birth of identity}

\author{
Cecília Zokner* \\ Velho, para quem deseja conhecer o Rio Grande, o Louco do \\ Catí é a receita. Como quem quiser saber como se pode escrever \\ um livro inteiro sem descrever o seu personagem, entretanto \\ sugerindo a sua figura, com palavras daqui e dali, \\ transformando-o num ser marcante. \\ Cecília Machado Bordini em carta a seu pai.
}

Contar se torna difícil, já dizia Honoré de Balzac, citado por Oscar Tacca, no Prefácio a Scènes de la vie privée, constatando "que todas as combinações possíveis parecem esgotadas, que todas as situações se cansaram, que o impossível foi tentado" (TACCA, 1971, p. 1). No entanto, Dyonélio Machado na simplicidade (aparente) de sua narrativa faz com que nela algo de novo perpasse, seja na construção da frase, na estrutura do relato, na criação do personagem em O Louco do Catí, publicado em 1942, pela Editora Globo de Porto Alegre, seu segundo romance, Sua estreia na ficção, com Os ratos, se dera dois anos antes. O Louco do Catí se constrói numa sucessão de cenas, em que se movem mais de cem personagens, entre os quais, segundo Philippe Amon, citado por Beth Brait, alguns funcionam "como elementos de conexão e que só ganham sentido na relação com outros elementos da narrativa pois não remetem a nenhum outro signo exterior" (BRAIT, 1987, p. 46). Algum detalhe no trajar, um gesto, uma frase, a profissão - nem sempre possuem um nome - os distingue. Por isso, de certa maneira, o Louco do Catí ${ }^{1}$, fio condutor da narrativa, terá com eles certa semelhança se forem levados em conta a sua caracterização que, segundo Antonio Candido (CANDIDO,1970, p. 59), são os elementos que um romancista utiliza

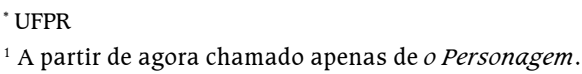


para descrever e definir o personagem. Em O Louco do Catí, o físico, os gestos, as atitudes e a voz serão sempre muito vagos no que ao personagem se refere. Personagem sem nome será designado por vários substantivos tanto pelo narrador quanto por alguns personagens. Na verdade, o romance já se inicia com um substantivo que, seguido de um adjunto adnominal o situa, também, num espaço determinado: o passageiro do bonde. 0 Personagem será referido também por: moço, este aqui, infeliz, o tipo, a figura, figura estranha, desconhecido, meio maluco, passageiro, camarada, homem, hóspede, aquela figura, viajante, o pobre, indivíduo, Norberto, o outro, amigo, sujeito, Catí, companheiro, Louco do Catí, maluco.

Prescindindo das informações sobre as circunstâncias da vida de Dyonélio Machado, sobre a profissão exercida (médico psiquiatra); sobre o período de prisão (ficou dois anos preso por delito de opinião), este trabalho será conduzido precipuamente a partir do texto que, esmiuçado, evidenciará a maestria com que o escritor gaúcho combina estratégias que se enlaçam para fazer do fragmentário e do incompleto um homem que se descobre.

Repertoriar as palavras que designam o Personagem ao longo do romance e os diálogos que sobre o seu nome se travam, assim como os termos usados para esboçá-lo, ainda que parcamente, evidenciarão uma identidade que parece se diluir em meio aos reveses, suavizados pela solidariedade presente em quase todos os episódios de que foi protagonista. Uma identidade que irá se construir, verdadeiramente, nos dois últimos capítulos do livro.

o romance tem início com o Personagem descendo de um bonde num fim de linha e se dirigindo a um armazém para comprar cigarros e fósforos. O dinheiro que estende ao dono do armazém e que já não fora aceito pelo cobrador do bonde não é suficiente para a despesa. Um dos rapazes, entre os que ali estavam, atento à cena, joga, de longe, a moeda que lhe falta. Logo, o recém-chegado estava incorporado ao grupo de Norberto, que lhe pagara os fósforos e seus três companheiros que o incluem na breve excursão que pretendem fazer até o litoral. Ao iniciarem o caminho de volta, Norberto decide seguir adiante e levá-lo junto. Uma viagem que irá se prolongar, cheia de incidentes, até o Rio de Janeiro de onde é enviado de volta ao Rio Grande do Sul, para chegar, enfim, a sua terra natal no extremo sul do Estado. Um percurso - feito a pé, de ônibus, de navio, de trem, de avião - que, mais do que paisagens e localidades, mostrará, em breves episódios, uma galeria de tipos das mais variadas condições sociais. Pessoas que, seja por um menor ou maior espaço de tempo, irão conviver com o Personagem, designando-o, como também o narrador, de várias maneiras, inclusive por pronomes. Tanto esses pronomes, como grande parte das ocorrências dessas designações - que são muitas, haja vista as dimensões 
exigidas para este trabalho - , farão parte de um texto maior.

Das palavras que o designam, acima mencionadas, por vezes, o uso se restringe a uma, duas, três vezes; outras há cuja ocorrência é bastante expressiva. Usadas uma única vez os sete primeiros exemplos: no desembarque, em Livramento, o coronel tomou um carro com um companheiro de viagem. Na conversa entabulada em que mutuamente se apresentaram, o outro perguntou: "E o moço?" (p. 260) [ele se refere ao Personagem]. Foi-lhe dada uma explicação e o indivíduo se deu por inteirado. Lopo, o amigo que o Personagem e Norberto fizeram no Rio de Janeiro, oferecera-se para levar o Personagem a São Paulo e se encarregar "de meter este aqui no trem pra o Rio Grande (e bateu-lhe educadamente no ombro)" (p. 149). Em Palmares, vendo-o dormir depois de o terem ido buscar no mato para onde fugira, alguém observa: “- Também! Depois do que o infeliz caminhou" (p. 41). E, quando foi tratada a possibilidade de sua transferência da segunda para a primeira classe do navio, um dos membros da alta administração do navio foi "despachado para o porão, afim de inspecionar o tipo, a figura" (p. 184). Pelo narrador, será chamado de figura estranha quando, na frente da hospedaria, em Palmares, "esbracejava" sob a luz da alvorada. No momento em que o pessoal do grupo com quem viajava considera a possibilidade de voltar no dia seguinte, para o desconhecido isso parecia algo de indiferente, isto é, coerente com o que havia sido constatado dele: "Não se lhe conhecia um rumo definido" (p. 17). E, na viagem de navio, há um momento em que o comandante se refere a ele como meio maluco. Também uma única vez aparece o termo passageiro para designar o Personagem e na voz do hoteleiro de Lages, que dá conta ao coronel do que lhe fora pedido por Geraldo, o motorista da empresa de transportes da capital: "Foi um passageiro que ele trouxe há quase um mês da capital. Não se sabe ao certo quem é" (p. 242). E, a palavra camarada, indicando o Personagem, parece ter sido empregada uma única vez na explicação que Norberto dá a Dona Rita quando ela quer saber quem é o Louco do Catí que viajava com o grupo: "Foi um camarada que encontramos no fim da linha. Topou o nosso convite [...]" (p. 36).

Será duas vezes designado por homem e, dentre as designações, os exemplos que seguem: logo na primeira página do romance, ao tentar pagar o ônibus com um dinheiro que não valia, o cobrador (no texto designado por condutor), prestou atenção no seu chapéu e "explicou de improviso ao homem do chapéu" (p. 11) o porquê de não aceitar o seu dinheiro. Ao se assustar e fugir para o mato, em Palmares, a decisão foi a de ir buscá-lo e chamaram o Janguta para ir "pegar o homem" (p. 38).

o designativo hóspede para o Personagem aparece duas vezes e, em ambas, acompanhado da palavra outro, (uma vez como adjetivo e outra 
como pronome). Ao chegar em casa, Geraldo (juntamente com o Personagem), escuta a mulher lhe dizer que fizera uma carne para ser comida com café. Geraldo aprovou, mas quis uma cerveja e mandou comprar. Só então, "informou que lhe trazia um outro hóspede" (p. 215). Mais adiante, enquanto a família de seus hospedeiros decidia se deveria levá-lo ou não a um passeio na cidade, do narrador (ou de um personagem) a constatação: "O outro, o hóspede, ainda não se levantara" (p. 226).

Nas visitas que Norberto fazia ao professor Castel, na sua doença, levava junto o Personagem que ficava esperando na sala. Porém, com o aumento das visitas, aquela figura atrapalhava e foi transferido, então, para uma banqueta no terraço. Sem o demonstrativo a anteceder o termo figura e sim um possessivo, ele aparece no penúltimo capítulo do livro quando já se encontra próximo do Catí. Caminhava sem se cansar e enfrentando obstáculos e "sua figura era apenas um pedaço de escuridão, fazendo um barulho: o barulho dum tranco sobre o chão alagado" (p. 275).

É no capítulo Viajando que aparece três vezes a palavra viajante para falar do Personagem. Aliás, é com ela, a única, grafada entre aspas na frase, que o capítulo se inicia: "O 'viajante' em meia hora estava pronto. Faltando a despedida [...]" (p. 211). Mais uma despedida que deve enfrentar e que o remete a esse momento do passado em que abandona a casa paterna. Deixa o navio em Florianópolis e de caminhão, ao lado do motorista, segue rumo a Lages. Ao cair da tarde param numa hospedaria para tomar café com leite. A dona do estabelecimento e o motorista falam sobre várias coisas "enquanto o viajante engolia a taça de café" (p. 213). Ao chegar a Lages, desceram na frente dum hotel e ao viajante que lhe seguia os passos, o motorista informa que não ficaria ali, iriam apenas entregar algumas coisas e logo seguiriam para sua casa onde a hospedagem lhes seria mais barata.

o termo pobre se referindo ao Personagem é usado sob o efeito da emoção. Ao saber de sua fuga, cheio de medo, para o mato, Dona Rita havia se penalizado e dissera: "O pobre [...]" (p. 35). Igualmente é com pena que a mulher do capitalista, diante do argumento de que eles deviam estar esclarecidos sobre o fato do Personagem ter estado na prisão, diz: "Ora, o pobre [...]" (p. 187). Na conversa com a visita que lhe recomenda cuidado com o dinheiro, principalmente devido à presença do Personagem na casa, Dona Miroca, que o hospedava em Lages, diz “- O pobre!” (p. 225) antes de se referir a sua bondade para com as crianças e a sua ajuda para tirar água do poço.

O capitalista se refere a ele como indivíduo, ao observar que, de fato, seria difícil seguir-lhe os passos, viajando em classe diferente da sua, "uma separação severa" pois "para o responsável da ordem a bordo, um viajante de segunda (quanto há também viajantes de primeira) é tão diferente 
destes últimos como se houvesse, realmente, nascido nessas acomodações inferiores" (p. 184).

Por Norberto será chamado, conforme sugestão de Lopo, a partir do momento em que subiu a bordo (pois viajava com passagem patrocinada pela polícia), ao ser apresentado ao capitalista que aceitara dele se encarregar (atendendo às instâncias da mulher que o a acompanhava). Mas na hora em que o navio se aproximava do caís de Santos, o capitalista observou que ele os faria perder tempo, levando sua companheira a perguntar "Ouem? Norberto?" (p. 185). Grafado entre aspas é a reafirmação da não veracidade do nome. Entre aspas aparecerá outras duas vezes: quando a companheira do capitalista lhe confidencia que "Norberto" já estivera na prisão e, ao prever que, em São Paulo, na casa de sua velha parente onde iriam se alojar, "Norberto" lhe faria companhia.

$O$ outro foi dito pelo motorista do ônibus quando chegaram a Tramandaí e ele quis se referir ao Personagem sem saber exatamente como, escolhendo as palavras: "O seu companheiro [...] (Ele hesitava). O outro [...] Aquele [...]" (p. 61). Na hora em que chegavam à prisão no Rio de Janeiro e Norberto foi informado de que a aparência contava em relação ao lugar em que ficaria o preso (aqui em cima/lá em baixo), ele fica procurando "com benevolência, qualquer aspecto agradável na figura do outro" (p. 97). E por o outro, a ele se refere o narrador quando na despedida do pessoal da pensão no Rio de Janeiro: "Eles vão me levar prá o Catí [...] sussurrou-lhe o outro" (p. 177). Em Lages, antes de se sentarem para comer, Geraldo convida: "Vamos lavar as mãos' e arrasta consigo o outro prá dentro" (p. 215). E à mesa lhe pergunta o nome: "O outro ainda engolia" (p. 217) e a resposta foi adiada. Porém, mais adiante considerou a resposta do outro. Antes, a amizade com Lopo lhe rendera uma calça e Norberto que "examinava a roupa do outro" (p. 138), no caso o Personagem, concluía que seu casaco não estava muito surrado.

Na chegada à prisão do Rio de Janeiro com outros presos, houve um momento em que os grupos se separaram. Diz o narrador: "com Norberto e o amigo vinham, afora os guardas, mais dois indivíduos de olhar espantado" (p. 100). Diante da cela, ele, que se debatera de medo, não atende a razões e é jogado para dentro. Um dos presos da cela comenta: " o carcereiro ficou com medo aí do amigo: ele não abriria hoje nem mais uma vez a grade" ( $p$. 103). O narrador retoma o termo amigo e o usa num itálico, levemente irônico. Ironia que em Dyonélio Machado é exemplar, diz Maria Zenilda Grawunder (GRAWUNDER, 1995, p. 39): "O amigo está exausto" (p. 103). Nas soluções encontradas para enviar o Personagem do Rio de Janeiro para o Sul, uma foi sugerida por Lopo levá-lo com ele para São Paulo: "Eu em São Paulo me encarrego de meter o nosso amigo [...] no trem" (p. 149). O 
coronel reparou que na estação de Caxias o Personagem não comprara passagem para Porto Alegre como estava previsto mas, para Santa Maria e lhe pergunta: "O amigo não é então de Porto Alegre?" (p. 251). Já em Santa Maria, o coronel o levou, embora chovesse muito, para o centro da cidade e conversou com ele sobre a estadia em São Paulo, perguntando: "E o amigo gostou?" (p. 254).

Preocupados, os rapazes com quem viajava, ao sabê-lo enfiado no mato sob o impacto do medo, acatam Seu Ricardo, dono do hotel, que decide: "Mas o que importa no caso é pegar esse sujeito" (p. 36). Durante o almoço na casa de pensão do Rio de Janeiro em que se falou das dificuldades relacionadas ao Personagem, Dona Amélia, disse que já fora informada "e designou o sujeito" (p. 165). No navio, a mulher do capitalista, ao se aproximar a hora da primeira refeição, "fez questão de ver o sujeito lá na segunda [classe]" (p. 138). E ao chegar em Santos, o capitalista considerou que, se o levassem junto a São Paulo, "o sujeito esse" (p. 185) os faria perder tempo. Também no navio, no episódio em que o marinheiro clandestino é mandado para a prisão e que o Personagem relaciona com o Catí, ninguém entende o seu grito de susto. Na hora em que abandonava o navio para ir pegar o caminhão para Lages, despediu-se do Comandante e do marinheiro. o Dr. Valério, que se ocupara dele até então, recomendou que não se demorasse, pois arriscava-se a perder o caminhão. "O sujeito tocou-se pela prancha abaixo" (p. 212). Ao desaparecer, logo depois de descer do avião, na fronteira, o ajudante de piloto opina se não valeria a pena puxar o sujeito de dentro do mato e mais adiante afirma: "Um sujeito assim é capaz até de agredir" (p. 272). E quando alguém pergunta por que terá feito isso (correr em direção ao mato) uma voz anônima pergunta: "O sujeito? [...]" (p. 272). Em Lages, acompanhando o coronel até o carro, o hoteleiro lhe diz em voz baixa que lá fora estava um sujeito à espera deles.

Em Lages, na casa em que se hospedara, uma visita de Dona Miroca, sabedora de que na casa havia um dinheiro extra trazido pelo seu marido pra comprar cera, pergunta se a importância está bem guardada mesmo, pois, reticente, ela continua, "uma casa com hóspedes, com gente desconhecida [...] Sobretudo êsse Catí, que tinha um ar tão estranho e que ninguém sabia donde vinha [...]" (p. 225). Insinuações que levaram Dona Miroca a induzir o marido a mandá-lo embora, acrescentando: "Não pelo Catí, coitado [...]" (p. 230). Um dia, em conversa com a mulher do professor Castel, ela diz a Norberto o quanto o marido havia se empenhado para conseguir tirar o Catí da prisão. Ao guardar na maleta do Personagem a escova de dentes, o pente e o sabão que ele trazia no bolso da capa, Dona Miroca vê um par de sandálias, já gastas e põe-se a olhar: "Nunca vira seu Catí de sandália" (p. 239). Logo depois ela lhe diz: "Eu botei uma 
lembrançazinha dentro da mala, seu Catí. É presente de Lourdes" (p. 240). Algum tempo antes, ela precisava sair mas não podia deixar a casa entregue às crianças. "É exato que havia o seu Catí. Muita coisa ele repararia" (p. 222) e " as crianças estavam se dando muito bem com seu Catí" (p. 222). E, exemplo perfeito da faceta trocista de Dyonélio Machado, a sequência em que o Personagem e Norberto chegam na casa do professor Castel. O doutor já dissera para a empregada que ao chegarem os mandasse entrar. E como ela também já havia recebido ordem de só permitir a entrada na casa a quem fosse doutor, ao fazê-los passar, disse: "Passe doutor (Norberto ia na frente). Passe Dr. Cati" (p. 139) [em itálico no original]. Em outras sequências, há, também, como que um contraponto "risível/dramático", visando esmaecer autoridades. É o caso da figura do delegado de Araranguá que tinha "por hábito andar sempre resfriado, a voz nasalada. Ele mesmo só se curava em último caso. Era moço e tinha gosto (rapaz de muito gosto), tinha gosto em andar assim, com a voz velada, rouca e íntima" (p. 71) e o descaso para com os homens que recebera ordem de prender; ou do comandante do navio que diante de um clandestino que fora posto a trabalhar no porão e é acusado pelos marinheiros de conspirar contra o comando, pergunta o que ele dissera e por ter dito "Huum [...]", mandou que o metessem nas grades; ou, ainda, da consulta pública, verdadeira aula sobre um homem de saúde altamente prejudicada, onde o professor prova que, apesar de todas as evidências, o paciente não tinha nada.

Das vinte e duas ocorrências da palavra companheiro, a exemplificação será por conta de algumas. Na praia onde ficara com o Personagem, decidindo não voltar com o grupo do passeio, Norberto deu um longo passeio pelo povoado, seguido do companheiro. Pagou-lhe a conta do hotel e o convenceu de fazer um bom trecho de praia que eles não conheciam, viajando no estribo pois não havia mais lugar no ônibus que seguia para Capão da Canoa. Quando se acomodaram, o motorista perguntou se estava tudo bem e Norberto espiou o companheiro. Na chegada a Tramandaí, Norberto sentiu-se indisposto e optou por comer, com o companheiro, uma sardinha com pão. A caminho, outra vez, de Capão da Canoa, os passageiros do ônibus decidiram tomar banho de mar antes da chegada. Norberto já viajava com o calção de banho por baixo da roupa: "Havia abandonado a sunga prá o companheiro" (p. 61). Em Capão da Canoa, perdido o entusiasmo pelo mar, depois de alguns dias, Norberto jogava a maior parte do tempo. "O companheiro esperava invariavelmente num canto, na semi-obscuridade" (p. 63). Desejando seguir viagem, o plano foi seguir a pé até Torres. Norberto fez o cálculo que em dez minutos faria um quilômetro. Saíram de madrugada e seu passo era mais firme, quase militar, porém "o trancão do companheiro, o seu trancão de maluco, vinha ele observando, 
que coisa, (está vendo?) que coisa mais indicada praquele gênero de viagem" (p. 64). Em Torres, Norberto compra duas passagens no Expresso do Norte que chegaria a Araranguá às nove horas mais ou menos. Enquanto tratava desses preparativos "o companheiro, esse, arriava onde quer que chegasse" (p. 65).

O Personagem é designado por Louco do Catí ${ }^{2}$ mais de trinta vezes, mas somente a partir do capítulo Música negra, da segunda parte do romance. Norberto e o Personagem são levados para a cadeia, "isolada, recortando-se muito alta no céu fosforescente, com alguma luz mortiça nas janelas gradeadas, uma massa parda, que os esperava" (p. 101). Determinaramlhes o cubículo 14 e, quando foram levados para lá, o Personagem "teve um movimento de fuga. Quis retroceder. Um dos guardas pôs-lhe a mão. Mas ele já soltava um grito: É o Catí! Não me digam que não! E depois de uma respiração ruidosa e difícil, numa voz berrada e choramingada a um tempo: Não me levem prá o Catí!" (p. 101). E logo na manhã seguinte, quando o "faxina" [entre aspas no original] aparece distribuindo o café, um preso da cela enfrente a deles aparece com uma caneca cheia na mão e diz: "O Louco do Catí está precisando de uma boa dose disto [...] e se ouviu, vindo do fundo de sua cela uma risada rápida." (p. 107). Depois, Norberto ficou sabendo que a direção da penitenciária era acusada de "servir no café dos presos uma mistura anafrodisíaca" (p. 109). Embora as outras designações continuem a lhe serem conferidas, a partir de então, ele também será designado por Louco do Catí, seja pelo narrador, seja pelos personagens.

Embora seja mencionado quase cento e vinte vezes o termo maluco, designando o Louco do Catí, apenas alguns exemplos dentre essas ocorrências serão mencionados: aparece pela primeira vez na página 18. Incorporado ao grupo nesse armazém de fim de linha de Porto Alegre, é somente quando já estão viajando que o chofer o designa por maluco pois até então ninguém lhe perguntara o nome ou conversara com ele. Ao tomarem conhecimento do nome de um dos rapazes que viajava junto, Maneco Manivela, o chofer que, no entanto, o conhecia há tempo, conclui que seu nome era engraçado. "De certo é um apelido. Os dois [o chofer e Norberto] voltaram-se vivamente. Mas, o maluco já estava, outra vez, olhando pra frente, pra longe [...]" (p. 19). Na parada que fez o grupo em Palmares no hotel do seu Ricardo, pediram um café com leite, mas decidiram não dar de comer ao maluco. Ele ficara lá para os lados do carro, talvez sem fome, pois na parada que haviam feito na estrada embaixo de uma árvore, onde repartiram um pedaço de carne seca cheirando a ferro, a graxa mineral, que estava guardado na caixa de ferramentas, o "maluco engolira o seu bocado com a sofreguidão serena e irracional dum cachorro, sem mastigar, o focinho horizontal, olhando para

\footnotetext{
${ }^{2}$ Uma vez aparece o termo louco em letra minúscula, provavelmente lapso da tipografia.
} 
diante" (p. 26).

Em cada uma dessas designações, inseridas em frases pronunciadas pelos personagens ou naquelas pertencentes à voz do narrador (como que imparcial, descomprometida), há uma inegável e cordial aceitação do alheamento em que vive o Personagem e a consequente possibilidade de exercer influência sobre ele.

Se, por um lado, está patente e intenção de Norberto ao incorporálo ao grupo e depois convencê-lo a continuar a viagem em sua companhia, os demais personagens o aceitam, quase sempre, com afabilidade, sem parecer se preocupar em saber quem é ou como se chama. Há, porém, momentos em que algum personagem se interessa ou mostra alguma estranheza a respeito do seu nome, alguns diálogos assim o demonstram.

Quando Norberto vai falar sobre a liberdade do Personagem, ainda na prisão, com o professor Castel, ele explica porque a sua inocência foi reconhecida por eles [em itálico no original], o pronome significando, certamente, as autoridades: ou foi raptado por Norberto ou foi por ele coagido a acompanhá-lo para despistar a polícia. Porém, ao se referir ao personagem, o designa por maluco, um pobre louco, o "o Louco do Catí - não é assim que o chamam?" (p. 131). Porque, além de conseguir, com o diagnóstico a saída do Personagem da cadeia, pouco parece se interessar por ele ou desejar conhecer o e seu verdadeiro nome. Indiferença que, aliás, também demonstra em relação aos pacientes que atende em público, na clínica, nos dias de consulta geral quando, então, no anfiteatro, exerce a cátedra; Geraldo, o motorista do caminhão que o leva como passageiro de Florianópolis até Lages, apenas vai ter curiosidade pelo seu nome, ao chegar em casa e sentarse à mesa. Para a mulher, dissera ter tido aquele companheiro de viagem que perdera o ônibus. Em meio à refeição lhe pergunta "'Como é seu nome, mesmo?' O outro ainda engolia. Suspendeu-se um momento. $O$ dono da casa viu sua atrapalhação. 'Engula primeiro' sugeriu-lhe. Foi o que ele fez. E falou depois num apelido [...] num apelido que ultimamente [...] 'Como é o apelido?', 'Ah! isso mesmo', considerou, ao ouvir a resposta do outro" (p. 217). E se lembrou da conversa na agência, em Florianópolis onde havia sido aventado avisar a polícia. Mas não pensava ter perigo, disse baixo para a mulher e insistiu: "Você não faz questão de ser chamado por todo o nome, naturalmente [...]" (p. 217). Interrompeu-o a voz da mulher, perguntando pelo nome. $\mathrm{O}$ marido reconheceu que apelido ou nome era a mesma coisa, concluindo que "Catí é mais curto" (p. 217). E relatou à mulher o que fora o Catí (" os horrores, as torturas, as perseguições, os degolamentos" - p.218) e acabou achando que seu hóspede nada tinha a ver com aquilo.

Um outro personagem de tais fatos se mostrará conhecedor. No navio onde viajava o Personagem, ele assustando-se com a prisão do 
marinheiro gritou "Catí". O médico se aproximou e lhe perguntou de onde ele era. "Os outros foram os que lhe ministraram informações. Poucas, entretanto. "Há bastante tempo não ouvia falar no Catí. Êsse pobre homem teve o mérito de me acordar uma velha recordação' disse o médico" (p. 202).

Igualmente, em outras duas sequências, aparecem menções ao seu pretenso nome. Conversando com Norberto, o doutor Lourenço Marques, em determinado momento, pergunta se eles eram do sul. E continua: "'Mas Catí [em itálico no original] não é nome [...]', 'Não, não é o nome dele', esclareceu Norberto (Aquele embuste involuntário não podia prosseguir). 'Percebo', justificou o médico 'é um diminutivo, uma abreviatura de gracinha, que se põe nas pessoas em casa [...] Ele talvez mesmo se chame Catarino $[\cdots] ”(p .143)$.

E, embora apresentado, ao entrar no navio como Norberto e assim ser tratado alguma vez, o capitalista que dele se encarregou soube mais tarde que esse nome não era o seu "a passagem com a qual viajava, passagem fornecida pela polícia [...] lhe pertencia tanto, quanto aquele nome" (p. 186) e a ele se referia como indivíduo, sujeito esse, esse pobre homem.

o fato de chamá-lo indistintamente de várias maneiras e entre elas as que o definem como incapaz - ou, talvez, por isso mesmo - fez com que muitos daqueles com os quais conviveu se prestassem a ajudá-lo, abstraindo-se, porém, de levar em conta a sua opinião ou o seu querer.

Não é dado a conhecer ao leitor os argumentos de Norberto para convencer o Personagem a se juntar ao grupo. Porque, se a sua chegada ao armazém é relatada, há uma completa ausência de informação quanto a sua anuência em participar da viagem. Bem mais adiante, pelas palavras do professor Castel, poderá ser compreendida a razão de Norberto em fazêlo parte do grupo - despistar a polícia que estava no seu encalço - e o desejar mandá-lo de volta para o Sul quando, ele, Norberto, já se acomodara, isto é, já conseguira emprego no Rio de Janeiro.

Numa oportunidade, Norberto perguntará o que acha, embora a pergunta signifique de per si uma afirmação: quando estão indo a pé pela beira da praia de Capão da Canoa até Torres e param para resolver se caminhariam junto ao mar ou pelas dunas, aproveitando para comer. Norberto, prudente, racionava os alimentos que levara, mas como haviam saído cedo, sem café, "era preciso restaurar bem a força perdida na areia. 'Não pensa assim?'” (p. 64) pergunta ao Personagem que, certamente, concorda o que seria muito difícil não acontecer. Porém, durante a continuação da viagem - Torres, Araranguá, Florianópolis, Rio de Janeiro, Norberto o irá conduzir. Comandará as suas atitudes: manda que tire o boné para se sentar à mesa no almoço com os demais passageiros do ônibus; tira-lhe o boné para que fique de recordação aos outros companheiros de cela na cadeia de 
Florianópolis; veste-o com a calça que Lopo, um amigo feito no Rio de Janeiro, lhe consegue e com o velho casaco e lhe põe o chapéu na cabeça. Logo no início da viagem, um dos rapazes lhe sugere que tire o casaco pois o calor aumentava. Igualmente, no restante da viagem, os que dele se ocupam lhe providenciam os meios de seguir viagem e, inclusive, a custeiam. No navio, para respeitar o regulamento ao ser transferido da segunda para a primeira classe, veste-se com a roupa que lhe dá o capitalista, ainda que lhe fique muito grande; em Lages, Geraldo, seu hospedeiro, decide se o leva ou não para a feira na cidade; outrossim, lhe providencia a partida de Lages e o Personagem acata a decisão. Como aceita ser levado a Santos pelo casal que o cuidava a bordo, descer do navio em Florianópolis e em Paranaguá com o doutor Valério, da estação de trem de Livramento ser conduzido a "reboque" pelo Coronel para o hotel, viajar de avião, uma vez que a chuva impedia que seguissem por terra, com a passagem paga pelo coronel.

Porém, embora se submeta aos que dele se ocuparam, deixandose levar e trazer, alimentar e vestir, o Personagem vai se mostrando, por algum detalhe de seu físico ("cara escura", "dedos esguios", "dorso curvo", "grandes orelhas pendentes", "descarnado"); uma ou outra referência no trajar (colete "comum de pano escuro") e o que lhe foi dado: o calção verde desbotado, a capa de borracha, a roupa folgada demais, os sapatos que lhe ficam grandes e o chapéu. Um chapéu já mencionado e descrito no primeiro parágrafo do livro e que, na opinião de Norberto não pode lhe ser tirado, pois está em perfeita harmonia com o colete. Mais adiante, porém, já não usa esse chapéu e sim o boné de brim com pala verde que, ao saírem da prisão, Norberto lhe diz para deixar de lembrança aos companheiros de cela, dando-lhe o seu, de formato diferente, comprado em Montevidéu. É o chapéu que passará a usar. Porém, sobretudo, o Personagem se mostra por gestos e atitudes, desvendando um perfil que se desenha além do medo (de gritos, de grades, de figuras que lembrem violência ), das marcas do passado (terror transmitido pelos adultos, o desgarrar-se da casa paterna), da alienação (um cismar, um olhar perdido num ponto ou na paisagem distante, uma divagação que o isola dos que o rodeiam).

Seus movimentos são marcados pela lentidão, por vezes pelo atrapalho: não poucas vezes, responde ao que lhe perguntam, expressando o sim e o não com um gesto muito lento da cabeça. Seu caminhar, "sozinho, incerto" ou um "meio trancão". Frequentemente, se atrapalha. Para subir a escada da pensão onde Lopo mora e ele e Norberto dormem escondido, devem sincronizar os passos mas o dele não "ritmou bem" com o dos outros dois. E, na viagem para Caxias, ao deixarem Lamb em Vacaria, esperou que o coronel, em cujo carro viajava, se despedisse e quando Lamb passou perto 
dele "espichou-lhe um braço. Quase lhe bateu na barriga. Lamb deteve-se. Pôs-lhe o olhar frio. Mas compreendeu. Até sorriu [...] E estendeu-lhe também a mão, despedindo-se, desejando-lhe uma feliz viagem [...]" (p. 247). Tomandoo sob sua proteção, o doutor Valério, na escala em que o navio faz em Florianópolis, se interessou em saber os horários de ônibus para Lages e, como era domingo, consultava os cartazes impressos, colados nos vidros. o Personagem também se aproximava "querendo ajudar o doutor, mas sem saber bem no que” (p. 209). E na casa de dona Josefina, a velha parente da companheira do capitalista que os hospeda em São Paulo, de manhã, primeiro ele ronda o quarto de seus protetores, indo e vindo pelo corredor. Mas, como eles não saíam, "ele baixou, muito sutil. A escada acabava na porta da frente. Puxou cautelosamente o trinco [...]. Foi arrastando com cuidado a porta pesada e lavrada" (p. 194). Ao tomar banho no improvisado "sistema", inventado pelos presos na cadeia do Rio de Janeiro, "curvava-se muito [...] no cuidado de não ir de encontro à instalação e desconjuntá-la" (p. 114).

E, assim, embora solidário, cuidadoso e gentil no trato com os demais, no que se refere aos seus interlocutores, ele se alheia. Não poucas vezes responde ao que lhe perguntam, expressando o sim e o não com um gesto lento de cabeça, ou silencia porque ignora a resposta. Ao serem presos no camarote do navio, em Florianópolis, Norberto lhe pergunta se ele enjoa. "Ele respondeu qualquer coisa" (p. 89). Porém, em todos os diálogos, que não são muitos, em que o Personagem é um dos interlocutores, sua voz não é ouvida. Ou porque não responde ou porque o narrador elude a sua resposta por um silêncio: ao falar da casa onde o Personagem ficaria, em Lages, é referido que ela ficava numa rua afastada e possuía uma espécie de sótão habitável. "Lá é que o maluco ia se alojar. Não ficava bem?" (p. 215). Sem ser antecedida do sinal gráfico que introduz o diálogo e sem identificação de quem haja formulado a pergunta, ela não teve resposta. Ou por estar inserida no texto narrativo: na prisão do Rio de Janeiro, um dos companheiros de cela dispõe das roupas convenientes para o banho de sol. Para Norberto, o casaco de pijama. Para o Personagem, só o calção e voltando-se para ele, comenta "Prá o companheiro não faz diferença [...]" (p. 111). A resposta aparece na linha seguinte e expressa pelo narrador: "Não, não fazia". Uma estrutura de diálogo que aparece, também, em outras sequências. Ou, ainda, devido às zonas de sombra que, não somente no que se refere aos diálogos, abundam no relato. Um exemplo está no trecho em que, antes de iniciar a viagem para Caxias, o coronel se dirigia ao Personagem, fazia perguntas e foi indo para o carro, conversando com ele. As perguntas (e respectivas respostas) não estão presentes no texto, como tampouco o mote da conversa. Assim, sua voz se faz ouvir apenas para expressar uma vontade "Eu quero por terra" (p. 148) quando Lopo e Norberto tratam de sua volta para o Sul e 
o funcionário pergunta se ele pensa "em voltar por mar" (p. 148). Ao responder, sua "voz soou no gabinete com um tom estranho, subterrâneo. Mas ele não tinha outro desejo a expressar e assumiu, outra vez o ar indiferente" (p. 148). Além dessa breve frase, sussurra, fala ou grita só para exprimir o medo. "Eles vão me levar prá o Catí [...]" (p. 177) sussurra para Nanci quando o levam embora da pensão onde morava, no Rio de Janeiro para embarcá-lo no cais do porto. Deixa ouvir uma voz de terror, no momento em que Norberto é preso "Isto! Isto é o Catí" (p. 67). E, ao serem levados para a cela na cadeia do Rio de Janeiro, ele quis fugir, o guarda o segurou e "ele já soltava um grito: É o Catí. Não me digam que não! E depois de uma respiração ruidosa e difícil, numa voz berrada e choramingada a um tempo: Não me levem pra o Catí!" (p. 101) Sequência que, entre espaços em branco, assinalados por asteriscos, em itálico e entre parênteses, uma lembrança do passado: "(O que é que vão fazer com o homem, mãe? Vão matar ele lá no Catí)". Finalmente, vendo o comandante que ele conhecia do hotel em Livramento e da viagem de avião, sob a luz da tarde cinzenta, "a sua figura alta e negra, tinha um aspecto estranho, lendário [...] 'O Catí! O Catí!' o maluco disse isso, atirando as palavras nas costas da figura negra - como cuspos, e fugiu à disparada" (p. 271).

Porém, há momentos em que se mostra lúcido. Em Lages se embevece com o pasto "polvilhado de branco" (p. 219). Ensaia, molhando os sapatos, "um passo em cima da geada" (p. 219); entende o grotesco da história contada por Norberto cujo protagonista fora um conterrâneo seu e esboça (talvez) um sorriso nesse "leve repuxo dos cantos dos lábios" (p. 154) que deixou Norberto "surpreso e entusiasmado" (p. 154); paga a sua passagem para Santa Maria quando todos imaginavam que voltaria para Porto Alegre. Mas, teve medo ao ser trancafiado, em Florianópolis e se aproximou, encolhido de Norberto para lhe perguntar se não seria o Catí; e, outra vez, na hora do banho de sol dos presos, no Rio de Janeiro, ao ver tanta gente batendo com os tamancos nas degraus de ferro, "encolheu-se, procurou uma proteção junto ao amigo" (p. 112). Antes, ao ser levado para a cela, "teve um movimento de fuga. Quis retroceder [...]. O guarda segurouo com força. Foi arrastando-o para a frente. Ele se debatia. E sempre protestando que não queria que o metessem no Catí" (p. 101).

E próximo do Catí, conduzido por um ou outro, ele chega. No pouso forçado do pequeno avião em que viajavam, junto à fazenda, uma "capa preta de botões dourados" (p. 270) que esvoaçava ao vento, a "figura alta e negra" (p. 271) do comandante Amilívio primeiro lhe deu um medo, cuja explicação está no relacionamento que faz com essa lembrança próxima ("homens vestidos de preto, de dólmans pretos onde luziam reflexos pretos ensopados de sangue" p. 280), e com essa outra que o assaltara quando 
fugira, em Palmares para esconder-se no mato: uma cavalgada de noite na rua deserta, reflexos metálicos de botões dourados nos dólmans pretos, bater de espadas, "caras pálidas, fantásticas, em uniformes negros, lendários" (p. 34). O medo o fez se encolher e, então, correu para desaparecer na intempérie numa fuga à qual se submete: "Estava escrito que haveria de chegar assim, todo degradado ao castelo ('um castelo que tinha um pátio sombrio, um pátio que tinha um poço, um poço que tinha gente [...]')" (p. 280).

Os três últimos capítulos do romance irão mostrá-lo transformandose, transformado. $O$ mato por onde se adentrara lhe oferece lembranças da meninice. Na longa viagem que fizera, também lembranças de um passado remoto, de sofrimentos antigos, haviam-se apresentado, rápidas, pela mente: o homem preso cujo destino era a morte no Catí, os índios maltrapilhos cuja "cara escura parecia mais escura pelo medo" (p. 33) que descalços e atados uns aos outros estavam rodeados pela polícia, a partida de casa na madrugada, despedindo-se da mãe, "o eterno quarto triste, de abandono" (p. 25). Inserem-se, em meio à narrativa em breves textos, sequências independentes (inclusive separadas por espaços vazios) que somente encontrarão o seu sentido nessas páginas finais do romance quando o Personagem decide enfrentar esses fantasmas que o levaram à apatia pela vida. Nos grotões onde se internara, a noite chegara mais cedo e ele continuou sua marcha, atravessou a sanga e foi indo picada acima, seguindo pelo corredor, ladeado por arames farpados. Sabia que ia em busca do Catí. Com alívio se entregava "ao demônio conhecidíssimo de sua infância - o demônio dos fundos de quintal e das sombras que fazem ao luar as velhas cercas de pedra [...]" (p. 278). Caminhava sem parar, sob a chuva e com uma pressa nunca sentida. Não lutaria mais, não fingiria mais, compreendera que tudo o que lhe acontecera nada mais havia sido que "uma 'preparação' para aquele momento - o seu momento . Entrava como um cão na crise da sua vida. - Tinha mêdo (e fuzilou um olhar para os lados, procurando um amparo humano na solidão), tinha mêdo de botar a mão no rosto enxovalhado, e dar com o focinho dum cachorro [...]" (p. 280). Prenunciando este medo muitas vezes, na voz do narrador, é empregada, em várias sequências, a palavra focinho para lhe designar o rosto, bem como para designar o rosto de delegado de Araranguá. Assim, entre outras: "alongara o focinho para a frente e assim ficou" (p. 17), "avançava o focinho querendo ajudar" (p. 209), "ia metendo o focinho em cada coisa" (p. 188), "focinho impassível" (p. 157), "focinho indagador" (p. 87), "punha o focinho no ar" (p. 85), "metia muito o focinho no papel" (p. 123). E duas vezes o verbo farejar ("Farejou um pouco na porta [...]" (p. 195) "farejou muito todo aquele centro da cidade" (p. 208). 
Então compreendeu que em "sua humilhação inferior, quando muito era um [...] Homem-cachorro!" (p. 280). E lhe veio à mente que havia sentido sempre "a sua sofreguidão canina, quando engolia o seu tassalho de carne [...] os seus silêncios invencíveis de cão [...] uma vez que fôra encerrado num quarto - como um cachorro! [...] o olhar triste de animal que erguera, certo dia, para o rosto moreno de Nanci (a mulher) e que tanto a perturbara [...] E um rabo que abanava, ingênuo, a cada 'festa' [...]" (p. 280).

Agora ele tinha pressa, uma pressa que nunca tivera. A chuva caía forte na capa de segunda mão e as calças que Lopo lhe dera batiam molhadas nas suas pernas e os sapatos ganhos do doutor Valério, ensopados, faziam barulho de água a cada um de seus passos. Mas, já não tinha mais o chapéu, o chapéu que lhe dera Norberto (o passado estava sendo deixado para trás) e sob o céu onde as nuvens se deslocavam para longe, começando a deixar tudo claro, ele ia pondo os olhos nas flores, mas, ainda, "uns olhos, muito deslavados, de cão" (p. 282). Apareceu o sol e ele retardou o passo e o "jacto de ouro vinha encher-lhe a cara de uma camada tênue e viva, como uma casca reluzente e quebradiça de louça. A sua roupa que o temporal maltratara e aviltava, recebia um raio de luz e ficava tranqüilamente incendiando" (p. 282).

Diante dele, pôde ver "o sol atirando-se contra as próprias ruínas, inundando-as" (p. 282). O Catí, castelo construído na elevação, às margens do arroio, onde era exercido um poder cruel e sem entraves que se fez "legenda, real, verdadeira, de sangue, de morte, de terror feudal" (p. 30) já não mais existia, se desfizera com o passar dos anos. Sobressaltou-se. Estremeceu. Entendeu. "O homem-cachorro de ainda um instante quase não acreditava. Mas afugentava a assombração num relâmpago, para sempre [...]!” (p. 282).

Integrado nessa paisagem, em que o cinzento da chuva fora vencido pelo sol, o Louco do Catí se tornou capaz de sorrir na "tarde de ouro". Recuperava essa identidade que o medo fizera perder.

Esperançoso final utópico, aspiração nostálgica dos homens de que fala Georg Lukács (LUKÁCS, p. 78), mas coerente com o código verbal de Dyonélio Machado, código este no qual se inscreve, e não poucas vezes, uma crítica às instituições - inclusive a possível analogia entre o que acontecera na época da Revolução Federalista e na época da ditadura do Estado Novo - e que está imbuído, sobretudo, da crença num ser humano capaz de ser solidário.

Em O Louco do Catí, os atos solidários que se sucedem permitem ao Personagem ir fazendo o seu caminho, sem ter essa motivação de viagem de que fala M. Baquero Goyanes (BAQUERO GOYANES, 1970, p. 30), pois é 
sempre conduzido. Motivação que, no entanto, emerge no momento em que o Personagem se reencontra consigo mesmo. E ainda que Dyonélio Machado não se tenha atido, como postula Forster (FORSTER, 1969, p. 26; 48), à vida interior e exterior de seu personagem e, tampouco, o tenha explicado, ele se torna explicável. Mesmo desajeitado, mesmo que pouco fale ou se submeta à vontade alheia, o Louco do Catí se revela um personagem de comovedora e marcante presença.

\title{
RESUMO
}

O Louco do Catí é um dos personagens mais ricos e instigantes do romance brasileiro. Sua história anterior ao momento em que chega num armazém para comprar cigarros é desconhecida tanto quanto será após ter se libertado dos medos que o impediram de viver. Será lançado numa aventura que se instaura no itinerário de uma viagem durante a qual permanecerá alienado e submisso à decisão dos outros. No entanto, breves sequências inseridas no relato mostram que possui condições de decidir por si mesmo, e ele o fará nos três últimos capítulos do livro, assumindo a identidade que o medo havia impedido de desabrochar. Neste trabalho sobre $O$ Louco do Catí, romance de Dyonélio Machado, foram repertoriados: as palavras que ao longo do romance o designaram - pois é um personagem sem nome -, os recursos que o narrador usou para caracterizá-lo, assim como a sua trajetória em busca de si mesmo.

Palavras-chave: Romance brasileiro; Personagem; Identidade.

\begin{abstract}
The madman of Catí is one of the richest and most instigating characters of Brazilian fiction. His story is unknown to the moment he arrives at a suburban grocery store to buy cigarettes, as it will be after he frees himself of the fears that prevent him from living. In Dyonélio Machado's novel, he is thrown into an adventure that happens along a journey during which he remains alienated and submissive to other people's decisions. However, brief sequences show that he can decide by himself, as he will do in the last chapters of the book, when he assumes the identity which his fears have prevented from emerging. In this paper about $O$ Louco do Catí we will compile the words that name him throughout the novel - since he's a nameless
\end{abstract}


character - and the resource that the narrator uses to characterize him and his trajectory in search of himself. Keywords: Brazilian novel; Character; Identity.

\section{REFERÊNCIAS}

BRAIT, Beth. A personagem. São Paulo: Ática.1987.

CANDIDO, Antonio. et al. A personagem de fição. São Paulo: Perspectiva. 1970.

FORSTER, E. M. Aspectos do romance. Porto Alegre: Globo, 1969.

GOYANES BAQUERO, M. Estructuras de la novela actual. Barcelona: Editorial Planeta. 1970.

GRAWUNDER, Maria Zenilda. Nas asas do Borboleta. In: BARBOSA, Márcia Helena Saldanha; GRAWUNDER, Maria Zenilda. (Orgs.). Dyonélio Machado. Cadernos Porto \& Vírgula, n 10, Porto Alegre, Unidade Editorial, 1995.

LUKÁCS, Georg. Teoria do Romance. Lisboa: Editorial Presença,1965. MACHADO, Dyonélio. o Louco do Catí. Porto Alegre: Globo, 1942.

TACCA, Óscar. La voz del narrador en la estructura narrativa. Madrid: C. S. I. C. 1971.

Submetido em: 03/09/2008

Aceito em: 10/08/2009 
